\title{
FUSION MISTAKES AND A WAY OUT
}

\author{
BY JOSEPH M. PRICE ${ }^{1}$ \\ New York City
}

$\mathbf{I}^{\mathrm{N}}$

N REVIEWING the last municipal campaign in New York city, in pointing out the mistakes of Fusion, a distinction must be made between the Fusion government of the last four years and the conduct of the campaign to re-elect it. If an administration in the city of $\mathrm{New}$ York deserved re-election, it was that headed by John Purroy Mitchel. No former administration has had as broad an outlook of municipal functions as a whole, or has had as difficult a situation to meet fnancially in carrying out its projects. It must be recollected that for over three years of the life of this administration there has been waged this great world war. It was building and financing a great new subway system and it had a comprehensive scheme for the development of the railroad situation so intimately bound up in the development of the city as a port. Its conduct of the finances of the city, especially in putting an end to the pernicious system of issuing bonds for things which would be used up before the life of the bond; its limitation of the corporate stock budget; the pay-as-you-go policy, would in a few years have placed the city of New York in an impregnable financial position. Among other great reforms of the administration, one could mention the adoption of the zoning system, which will be of inestimable value to the orderly growth of the city, and which if adopted years ago, would probably have obviated the great fluctuation of realty values in the city of New York; and the adoption of a modern building code. In spite of these things it met with an overwhelming defeat.

THE QUESTION TO ASK OURSELVES IS WHY

Is it possible for an administration that does these things to be continued in office? Some say we were going too fast in New York city, others, that the real fault of the administration has been its lack of humanizing elements, still others, that in doing these things so many enemies have been made and so much opposition aroused that continued success is impossible.

I do not believe this, and am probably one of a great minority who believe that this administration could have been re-elected. It is true great opposition had been aroused by these things, an organized opposition, but it is a fact that the managers of the last Fusion campaign did not realize the strength of the opposition until it was too late. The influences that dominated the Fusion committee of 1917 from its very beginning

${ }^{1}$ Member executive committee, fusion campaign of 1917. 
naturally gave the impression that it was only the moneyed interests that were in favor of the mayor's re-election. The leaders really believed that money could re-elect the mayor, money not to be used for illegal purposes, but money for what they considered legitimate expenses, such as enormous sums for newspaper advertising, printing of pamphlets, billboard advertising, high salaries for expert directors of the various departments, most of which was spent in a perfectly puerile fashion. The point is, those directly responsible for the mayor's campaign had no vision of what the town was thinking about or interested in, nor did they have any political experience in managing municipal affairs or campaigns, though they were all good business men in managing their own affairs.

\section{CITIZENS' COMMITTEES}

Citizens' committees must make their own way into public confidence, they must justify themselves for their assumption of the direction of affairs. This committee did not secure the public's confidence and the town had no reliance upon its non-partisan character or its independence from party control. In this the town was thoroughly justified by the acts of the leaders in consulting the Republican leaders step by step in the formation of the committees' policies; not once during the campaign or in planning for it was the executive committee of the Fusion committee called together by its chairman for consultation, advice or information as to his plans. If it had been, many of the mistakes made, especially the proposal for spending such enormous sums, might have been obviated. The Republican leaders of the counties that make up Greater New York, care only for being represented on the ticket and except for the mayor, the nominee for president of the board of alderman and several county offices, the entire ticket was dictated by the Republican organization. In Brooklyn there was not a Democrat on the ticket. These facts were pointed out after the nominations by some newspapers friendly to the Fusion cause.

\section{LOSS OF THE REPUBLICAN PRIMARIES}

The fatal error, was of course, the loss of the Republican primaries. The excuse given by the Fusion leaders is that they took the advice of the majority of the Republican leaders, as to making a fight in the primaries for Mayor Mitchel. I would just as soon take the advice of the Kaiser as how to conduct the allied campaign on the western front. I would not take hostile advice in political matters.

The loss of the primaries by Mayor Mitchel with its attending irregularities, for which he was not in the least to blame, changed the whole psychology of the city. Before the loss of the primaries it was felt he could not be beaten and the talk was all that way; after the loss of the primaries the talk one heard around, even on the streets, was that "they did not see how he could win." 
I believe Tammany Hall can always be beaten in the city of New York with a united opposition. People may say the united vote of Mr. Mitchel and Mr. Bennett was not enough to elect Mitchel. True, but that is not the whole story. The Republican enrollment in Greater New York is over two hundred and fifty thousand, the combined Mitchel and Bennett vote a little over two hundred and twelve thousand, surely fifty thousand votes were cast for Mayor Mitchel by men not enrolled in the Republican party, which leaves the Republican vote for Mitchel about one hundred thousand short of its enrollment. I believe Mayor Mitchel could have had these votes if they had not been alienated by the tactics of the Fusion leaders, for it has been shown that the Republican enrollment is for state and national purposes only, over half of it will vote independently in municipal elections and cannot be controlled by the Republican leaders.

The point I am making is that the Fusion leaders threw away the great asset of a citizens' movement, such as elected Mayor Mitchel four years ago, by dealing in conference with the Republican leaders, submitting to their demands for places on the ticket for votes which they do not control. The committee four years ago nominated a ticket and told the Republican organization to take it or leave it. The excuse for this year's procedure was that the Republican organization had not recovered from the sores of four years ago and therefore must be the primary consideration this year. The fact is, a ticket dominated by the Republican organization cannot win in the city of New York, and the only hope they have to get anything is by their endorsing a citizens' ticket, not in dominating it.

Everything we have gained in our struggles in New York city for the last twenty years in having the citizens themselves nominate their ticket has been lost.

\section{THE NEED FOR A MUNICIPAL PARTY}

In view of these facts and an important new factor, I have come to the conclusion that the time is ripe for the formation of a permanent municipal movement, call it by any name you like, party, committee or league. I have previously been opposed to this, for the reason that I have been doubtful as to keeping it alive without patronage, which is the life of most political organizations. I believe, however, we now should be willing to risk this, for we have learned a great deal in this city since the Van Wyck administration of 1898-1901, as there has grown up a body of men who can be banded together that know city affairs and are working out municipal problems on a basis of "know your city."

The important "new factor" is the granting of votes to women in New York. The progressive women in New York city have taken an active interest in municipal affairs for years past. Here is a large body of new 
voters not yet aligned politically that could be brought into a purely municipal party and should be an antidote to the patronage seeker and a great influence in guiding the city along progressive lines, by giving them a place where they can work for their city on an entirely non-partisan basis.

\section{THE NEED FOR A MUNICIPAL PROGRAM}

Such an organization will stand or fall upon its municipal program. American political tradition has been that we should have a two-party government, why not a two-party government in municipal affairs as well as state and national affairs, but not dominated by national or state political lines, but upon the lines of municipal, social and economic progress. Such a party when the time came for the nomination of a city ticket should be absolutely non-partisan (as far as national parties are concerned) in its selection and should have no hesitancy in renominating a member of the sitting administration, if it believed he had made good in office; it should always be in a position to criticize the acts of the administration, friend or foe, and offer helpful and constructive suggestions. It would not, like the Fusion committee of 1917, work upon a municipal platform for two months, then hastily whip it into shape in two days, never again to be heard of during the progress of the campaign. Such a body would become acquainted with the needs and interests of the various sections of a great city like New York. It would build up a band of disinterested citizens who would work sincerely for its success, have a place where the young men and women could find vent for their civic enthusiasm; it would do away with trying in the last few. weeks of a campaign to effect a working organization; it would know before the beginning of the campaign which were "strike" organizations and which among them had merit; it would do away with financing various combinations of labor, nationality, race and color, to which so much time and money is devoted in a hastily constructed campaign organization; it would conduct between elections a speaking campaign of education, for reform must rest upon the intelligent understanding of the average citizen.

Such an organization need not entirely do away with the formation of a citizens' committee, but it would certainly obviate the necessity of it and would certainly prohibit the formation of any committee that was not a real citizens' committee. We must not forget that the other man believes in "good government" as much as we do, but he believes it can be secured in a different way. To be successful in our municipal movements, we must get that other man, he is the "average citizen"; if we don't, wewill never make a permanent success. I believe he can be gotten. 